\title{
HUBUNGAN DAYA LEDAK OTOT LENGAN DENGAN HASIL SERVIS ATAS PADA SISWA EKSTRAKURIKULER BOLA VOLI SMA NEGERI 1 PAGAR ALAM
}

\author{
Helen Purnama Sari \\ Universitas Islam Kalimantan Muhammad Arsyad Al Banjari Banjarmasin \\ Helenpurnamasari20@gmail.com
}

\begin{abstract}
ABSTRAK
Penelitian ini bertujuan untuk mengetahu hubungan daya ledak otot lengan dengan hasil servis atas pada siswa ekstrakurikuler bola voli SMA Negeri 1 Pagar Alam, manfaat dalam penelitian adalah memberikan gambaran tentang metode melatih servis atas bola voli yang baik dan sebagai bahan masukan dasar bagai proses penentuan program pembelajaran dan melatih, subyek dalam penelitian ini adalah siswa ekstrakurikuler bola voli SMA Negeri 1 kota Pagar Alam yang berjumlah 36 siswa, metode penelitian ini adalah metode korelasi dengan langkah-langkah pengumpulan data yang digunakan adalah observasi, dokumentasi dan tes, Dalam pengumpulan data pada penelitian ini menggunakan penjelasan, hasil dari penelitian ini Terdapat hubungan yang kuat antara daya ledak otot lengan dengan hasil servis atas bola voli pada siswa ekstrakurikuler bola voli SMA Negeri 1 Pagar Alam dimana Terdapat hubungan yang signifikan antara daya ledak otot lengan dengan hasil servis atas pada siswa ekstrakurikuler bola voli SMA Negeri 1 Pagar Alam dari hasil uji thitung lebih besar dari ttabel atau 8,745 > 1,697
\end{abstract}

Kata Kunci : Daya Ledak Otot, Servis Atas, Bola Voli

\begin{abstract}
This study aims to determine the relationship of arm muscle explosive power with the results of top service in volleyball extracurricular students at senior high school 1 Pagar Alam State, the benefit of the research is to provide an overview of the method of service training on volleyball which is good and as a basic input for the process of determining learning programs and train, the subjects in this study were 36 volleyball extracurricular members of senior high school 1 Pagar Alam State, the method of this study was the correlation method with the steps of data collection used were observation, documentation and tests, in collecting data in this study using the explanation, the results of this study There is a strong correlation between the explosive power of the arm muscles and the results of service on volleyball on volleyball extracurricular students at senior high school 1 Pagar Alam State where there is a significant relationship between arm muscle explosiveness and top service results in ball extracurricular students volleyball senior high school 1 Pagar Alam State from the results of the tcount test is greater than t table or $8.745>1.697$
\end{abstract}

Keywords: Muscle Explosion, Upper Service, Volleyball

Dipublikasikan Oleh :

UPT Publikasi dan Pengelolaan Jurnal

Universitas Islam Kalimantan Muhammad Arsyad Al-Banjari Banjarmasin 


\section{PENDAHULUAN}

Olahraga merupakan aktivitas yang sangat penting untuk mempertahankan kebugaran seseorang serta merupakan salah satu metode penting untuk mereduksi setress. Olahraga juga merupakan suatu prilaku aktif yang mengingatkan metabolisme dan mempengaruhi dan fungsi kelenjar di dalam tubuh untuk memproduksi sistem kekebalan tubuh dalam upaya mempertahankan tubuh dari gangguan penyakit serta setres. Oleh karena itu, sangat dianjurkan kepada setiap orang untuk melakukan kegiatan olahraga secara rutin dan tersetruktur dengan baik.

Olahraga bola voli merupakan salah satu cabang olahraga yang sudah berkembang di masyarakat luas, baik di klub-klub, kantor-kantor, desa-desa, maupun sekolah-sekolah. Hal ini disebabkan karena olahraga bola voli memerlukan peralatan yang sederhana serta mendatangkan kesenangan bagi yang bermain. Hal ini selaras dengan pendapat Mardiana dkk (2010: 20) bahwa" Olahraga bola voli sebuah bentuk permainan yang sangat menarik karena di dalamnya terdapat unsur kegembiraan, kerjasama antarpermain, dan banyak ragam gerak. Pemaianan sudah memasyrakat dan dilakukan hampir dseluruh plosok Indonesia.

Menurut Faruq (2009:11) pendekatan modifikasi ialah pendekatan yang dilakukan dengan berbagai variasi mulai dengan memperkenalkan bola voli, mengajak siswa bermain bola voli dengan harapan siswa dapat bermain bola voli dengan lebih semangat dan menyenangkan misalnya mengubah ukuran lapangan, jumlah pemain, ukuran bola dan tingginya net menjadi langkah awal untuk menjadikan anak-anak tertarik dengan permainan ini. Dengan demikian ekstansi semua pihak dalam permainan olahraga diharapkan tetap ditingkatkan, menyadari semakin pentingnya peranan olahraga sebagai upaya peningkatatn fisik maupun mental, peningkatan prestasi dan manfaat rekreasi disamping manfaat-manfaat lain yang bisa diperoleh aktifitas olahraga.

Namun dalam mencapai prestasi diperlukan pembinaan. Salah satu pembinaan dilakukan melalui kegiatan ekstrakurikuler di sekolah, agar dapat menumbuhkan bibit-bibit baru dalam cabang olahraga. Salah satu ekstrakurikuler yang dilakukan adalah ekstrakurikuler bola voli yang terdapat di SMA Negeri 1 Pagar Alam. Sehubungan hal tersebut, maka dalam upaya meningkatkan prestasi olahraga perlu diusahakan pembinaan yang terarah dan berkelanjutan lewat pemanduan bakat pembibitan pendidikan serta pelatihan olahraga yang didasarkan pada ilmu pengetahuan secara efektif dan efisien sebagai sarana mencapai prestasi yang optimal.

Berdasarkan hasil observasi peneliti di SMA Negeri 1 Pagar Alamsiswa ekstrakurikuler masih kurang teknik dasar permainan bola voli terutama dalam melakukan servis atas, kurangnya penguasaan teknik dasar siswa ekstrakurikuler bola voli SMA Negeri 1 Pagar Alamhal ini terlihat dari masih banyaknya bola yang tidak melewati net (menyangkut) dan keluar lapangan. Hal ini disebabkan karena kurangnya penguasaan dalam teknik dasar servis atas bola voli, dan kurangnya kekuatan daya ledak otot lengan saat melakukan servis atas bola voli.

Berdasarkan uraian diatas, maka peneliti ingin memberikan latihan dan meneliti tentang meningkatkan daya ledak otot lengan dalam melakukan servis atas bola voli dengan judul penelitian :"Hubungan Daya Ledak Otot Lengan Dengan Hasil Servis Atas Pada Siswa Ekstrakurikuler Bola Voli SMA Negeri 1 Pagar Alam".

\section{TINJAUAN TEORITIS}

Bermain bola voli pada dasarnya sangat mudah, yaitu bola dimainkan sebelum jatuh ke lantai dan diusahakan bola itu melewati atas jaring net ke arah lapangan lawan dengan maksud lawan tidak bisa mengembalikan. Didalam modul pembelajaran bola voli, di sajikan dasar-dasar permainan bola voli, strategi pembelajarannya, terutama pada perubahan beberapa aspek agar sesuai dengan kemampuan anak. Perubahan tersebut lebih memberikan kesempatan bergerak, keleluasaan berfikir, kebebasan bertindak lebih menarik dan menggembirakan (Mardiana dan Satya, 2010:5.20).

Menurut Indra (2010:40) Service adalah service dengan awalan melemparkan bola keatas seperlunya. Orang yang melakukan service (server) melompat untuk memukul bola dengan ayunan tangan dari atas. Menurut Beutelstshl (2012:8) Servis adalah sentuhan pertama dengan bola. Mula-mula servis ini hanya dianggap hanya sebagai pukulan searah, cara melempar bola untuk memulai permainan. Tetapi servis ini kemudian berkembang menjadi suatu senjata yang ampuh untuk menyerang. Adapun macam-macam servis ada dua yaitu: a) servis atas adalah servis yang dilakukan dengan awalan melemparkan bola ke atas seperlunya, b) servis bawah adalah servis yang dilakukan dengan awalan bola berada di tangan yang tidak memukul bola, melainkan bola dipukul oleh tangan yang telah bersiap dari belakang badan. Jadi teknik dasar ini tidak boleh kita abaikan, dan harus kita latih dengan baik terus menerus.

Menurut Tamat dan Mirman (2006:4.59) Passing adalah usaha seorang pemain dengan cara menggunakan suatu teknik tertentu yang tujuannya untuk mengoperasikan bola kepada teman seregunya. Dan passing terbagi menjadi dua, yaitu passing atas dan passing bawah. Menurut Indra (2010:42) Passing bawah (pukulan/pengambilan tangan ke bawah). Sedangkan menurut Beutelsthal (2007:22) passing atas adalah dengan cara menggunakan kedua tangan yang diangkat ke atas lurus agak didepan kepala, jari-jari tangan dibuka lebar

\section{Dipublikasikan Oleh :}

UPT Publikasi dan Pengelolaan Jurnal

Universitas Islam Kalimantan Muhammad Arsyad Al-Banjari Banjarmasin 
sehingga kedua jari tangan siap menerima bola. Smash adalah pukulan yang utama dalam penyerangan dalam usaha mencapai kemenangan. Sedangakan menurut Rahmani (2014:116) Smash merupakan teknik memukul bola dengan sangat keras dan terarah, untuk dimasukan ke daerah lawan

Dalam permainan bola voli remaja, melakukan servis tangan atas mungkin merupakan sesuatu yang menantang bagi siswa. Untuk menggunakan servis ini, siswa harus mampu melempar secara konsisten dan harus memilki daya ledak otot lengan serta koordinasi untuk memukul bola keatas jaring dengan menggunakan suatu gerakan melempar tangan atas. Servis adalah sebagai tanda dimulainya permainan dan sebagai suatu serangan yang pertama kali bagi suatu regu. Untuk memperoleh keseragaman gerak teknik servis, maka peneliti hanya menggunakan servis atas bola voli.Adapun cara untuk melakukan servis atas menurut Viera dan Ferguson (2004:30)..

\section{METODE}

Metode penellitian adalah cara digunakan oleh peneliti dalam mengumpulkan data penelitiannya (Arikunto, 2010:203). Penelitian korelasional (hubungan) ini dilakukan dengan maksud untuk memperoleh gambaran bagaimana hubungan daya ledak otot dengan hasil servis atas bola voli. Dalam pengumpulan data pada penelitian ini menggunakan penjelasan (ceramah) dimana peneliti menjelaskan terlebih dahulu apa yang dimaksud dengan daya ledak otot lengan dan servis atas bola voli serta jenis-jenis servis kemudian memberikan contoh servis atas yang baik dan benar. Penelitian ini menggunakan tes adapun pengertian tes adalah serentetan pertanyaan atau latihan serta alat lain yang digunakan untuk mengukur keterampilan, pengetahuan intelegensi, kemampuan atau bakat yang dimilki oleh individu atau kelompok, Arikunto (2010:193). Langkah-langkah pengumpulan data penelitian Observasi, Dokumentasi dan Tes, Data yang diperoleh kemudian dianalisis dengan menggunakan analisa deskritif statistik dan Teknik analisis data yang digunakan untuk menguji koefisien korelasi pada penelitian ini adalah product moment.

\section{HASIL DAN PEMBAHASAN}

Penelitian dilaksanakan di SMA Negeri 1 Pagar Alam dengan sampel 36 siswa, dalam penelitian ini menggunakan metode deskriftif melalui tes dan pengukuran. Penelitian ini bertujuan untuk mengetahui Hubungan Daya Ledak Otot Lengan Dengan Hasil Servis Atas Pada Siswa Ekstrakurikuler Bola Voli SMA Negeri 1 Pagar Alam. Adapun teknik pengumpulan data yang digunakan adalah menggunakan tes Vertkal Arm Pull (Work) dan Servis Atas Bola voli dengan enam kali kesempatan tiap siswa.

Setelah melakukan proses latihan dan pengumpulan data, maka selanjutnya peneliti melaksanakan analisis data dengan tujuan untuk melihat adakah hubungan daya ledak otot lengan dengan hasil servis atas pada siswa ekstrakurikuler bola voli SMA Negeri 1 Pagar Alam. Dalam penelitian ini peneliti mendapatkan data dalam bentuk tes yaitu :

Tes Vertikal Arm Pull (Work) untuk meningkatkan daya ledak otot lengan sebagai variabel bebas (X) yang diikuti oleh 36 peserta. jumlah variabel daya ledak otot lengan dapat diperoleh skor terendah 0,32 Meter dan Skor tertinggi 1,24 meter. Dari hasil penyebaran jumlah skor tersebut dapat diketahui skor rata-rata (mean) adalah sebesar 0,02. Tes servis atas bola voli sebagai variabel terikat (Y) yang diikuti oleh 36 siswa ekstrakurikuler bola voli SMA Negeri 1 Pagar Alam. hasil data pengukuran hasil servis atas bola voli diperoleh nilai tertinggi adalah 25 dan nilai terendah adalah 6. Dari hasil penyebaran jumlah skor tersebut dapat diketahui skor rata-rata (mean) adalah sebesar 0,52

Berdasarkan analisis data diatas telah diperoleh hasil dengan interval koefesien 0,60 untuk hubungan daya ledak otot lengan dengan hasil servis atas bola voli, berarti hasil itu menunjukkan bahwa kedua variabel tersebut saling berhubungan. Dimana dapat dilihat ke dalam tabel interprestasi korelasi nilai $r$ variabel bebas dan variabel terikat mempunyai tingkat hubungan yang kuat.

Setelah data dihitung menggunakan korelasi product moment yang didapatkan hasil 0,60. Kemudian untuk menyatakan besar kecilnya sumbangan variabel $\mathrm{X}$ dan $\mathrm{Y}$ bisa ditentukan menggunakan rumus koefesien diterminan sehingga mendapatkan hasil $36 \%$ artinya variabel bebas daya ledak otot lengan memberikan kontribusi terhadap kemampuan servis atas bola voli, sedangkan sisanya $64 \%$ ditentukan oleh variabel lain.

Latihan vertical arm pull (work) diberikan untuk meningkatkan daya ledak otot lengan dengan hasil servis atas bola voli tergolong kuat, artinya apabila daya ledak otot lengan semakin hari semakin ditingkatkan maka hasil servis atas bola voli semakin kuat dan semakin meningkat dan hasil yang diperoleh semakin maksimal. Hasil analisis data diperoleh dengan thitung lebih besar dari ttabel atau 8,745 $\geq 1,697$, sehingga dapat disimpulkan bahwa hipotesis penelitian diterima dan hipotesis nol ditolak.

\section{PENUTUP}

Dipublikasikan Oleh :

UPT Publikasi dan Pengelolaan Jurnal

Universitas Islam Kalimantan Muhammad Arsyad Al-Banjari Banjarmasin 


\section{SIMPULAN}

Berdasarkan hasil penelitian, analisis data, dan pembahasan yang telah dilakukan, dapat diambil kesimpulan sebagai berikut :

1. Terdapat hubungan yang kuat antara daya ledak otot lengan dengan hasil servis atas bola voli pada siswa ekstrakurikuler bola voli SMA Negeri 1 Pagar Alam

2. hal ini dapat dilihat dari analisis data dengan menggunakan perhitungan rumus korelasi didapat nilai sebesar 0,60 yang berarti adanya hubungan yang kuat antara daya ledak otot lengan dengan hasil servis atas bola voli.

3. Terdapat hubungan yang signifikan antara daya ledak otot lengan dengan hasil servis atas pada siswa ekstrakurikuler bola voli SMA Negeri 1 Pagar Alamdari hasil uji thitung lebih besar dari ttabel atau 8,745 > 1,697 .

4. Berdasarkan koefisien determinasinya daya ledak otot lengan memberikan kontribusi yang cukup besar terhadap servis atas bola voli $36 \%$.

\section{SARAN}

1. Bagi pelatih dan Guru PenjasorkesKarena terbukti daya ledak otot lengan ada hubunganya dengan hasil servis atas bola voli, maka bagi para pelatih maupun guru penjasorkes dalam mencari atlit khususnya dalam permainan bola voli hendaknya mencari atlit dengan kualitas daya ledak otot lengan baik.

2. Bagi atlet atau siswa

Bagi para atlet atau siswa setiap sebelum melakukan latihan servis atas dalam permainan bola voli hendaknya terlebih dahulu melakukan latihan vertical arm-pull (work) agar dapat servis atas dengan kuat dan terarah.

3. Bagi peneliti lain

Bagi peneliti lain yang akan mengambil variabel yang berhubungan dengan hasil servis atas, dapat digunakan sebagai referensi untuk menambah informasi yang dibutuhkan dalam penelitianya, serta diharapkan bagi peneliti lain untuk melakukan penelitian dengan komponen yang lain yang berhubungan dengan hasil servis bola voli, sehingga penelitian ini dapat digunakan sebagai bahan pertimbangan agar diperoleh hasil yang lebih dapat dipertanggung jawabkan.

\section{REFERENSI}

Arikunto,Suharsimi,2010. Prosedur Penelitian Suatu Pendekatan Praktik. Jakarta : Rineka Cipta.

Beutelstahl, Dieter. 2012. Belajar bermain bola voli. Bandung : CV Pionir Jaya.

Faruq, Muhammad Muhyi 2009. Meningkatkan kebugaran jasmani. Surabaya : PT Gramedia.

Indra, Ani, 2010. Mengenal bola voli. Jakarta : Ad-Print Mitra Pustaka.

Ismaryati. 2011. Tes dan pengukuran. Semarang : Universitas Negeri Semarang.

Mardiana, Ade dkk, 2010. Pendidikan jasmani dan olahraga. Jakarta : Universitas Terbuka.

Mikanda Rahmani,2014.Buku super lengkap olahraga. Jakarta : Dunia Cerdas

Tamat, Trisnowati \& Mirman,Moekarto, 2006. Pendidikan Jasmani dan Kesehatan. Jakarta : Universitas Terbuka.

Viera, Barbara L \& Fergusson, Bonnie Jill. 2004. Bola Voli Tingkat Pemula. Jakarta: PT. Rjagrafindo. 